\title{
The Effect of Cochlear-Implant-Mediated Electrical Stimulation on Spiral Ganglion Cells in Congenitally Deaf White Cats
}

\author{
Iris Chen ${ }^{1}$, Charles J. Limb ${ }^{1}$, AND David K. Ryugo ${ }^{1,2,3}$ \\ ${ }^{1}$ Department of Otolaryngology-HNS, Center for Hearing and Balance, Johns Hopkins University School of Medicine, Traylor \\ 510, 720 Rutland Ave, Baltimore, MD 21205, USA \\ ${ }^{2}$ Department of Neuroscience, Center for Hearing and Balance, Johns Hopkins University School of Medicine, Baltimore, MD \\ 21205, USA \\ ${ }^{3}$ Garvan Institute of Medical Research, Darlinghurst, Sydney, NSW 2010, Australia
}

Received: 8 December 2009; Accepted: 13 August 2010; Online publication: 4 September 2010

\begin{abstract}
It has long been observed that loss of auditory receptor cells is associated with the progressive degeneration of spiral ganglion cells. Chronic electrical stimulation via cochlear implantation has been used in an attempt to slow the rate of degeneration in cats neonatally deafened by ototoxic agents but with mixed results. The present study examined this issue using white cats with a history of hereditary deafness as an alternative animal model. Nineteen cats provided new data for this study: four normal-hearing cats, seven congenitally deaf white cats, and eight congenitally deaf white cats with unilateral cochlear implants. Data from additional cats were collected from the literature. Electrical stimulation began at 3 to 4 or 6 to 7 months after birth, and cats received stimulation for approximately $7 \mathrm{~h}$ a day, 5 days a week for 12 weeks. Quantitative analysis of spiral ganglion cell counts, cell density, and cell body size showed no marked improvement between cochlear-implanted and congenitally deaf subjects. Average ganglion cell size from cochlear-implanted and congenitally deaf cats was statistically similar and smaller than that of normal-hearing cats. Cell density from cats with cochlear implants tended to decrease within the upper basal and middle cochlear turns in comparison to congenitally deaf cats but remained at congenitally
\end{abstract}

Correspondence to: David K. Ryugo · Department of OtolaryngologyHNS, Center for Hearing and Balance · Johns Hopkins University School of Medicine - Traylor 510, 720 Rutland Ave, Baltimore, MD 21205, USA. Telephone: +1-410-9554543; fax: +1-410-9551317; email: dryugo@jhu.edu deaf levels within the lower basal and apical cochlear turns. These results provide no evidence that chronic electrical stimulation enhances spiral ganglion cell survival, cell density, or cell size compared to that of unstimulated congenitally deaf cats. Regardless of ganglion neuron status, there is unambiguous restoration of auditory nerve synapses in the cochlear nucleus of these cats implanted at the earlier age.

Keywords: auditory nerve, cochlea, cochlear nucleus, cochleosaccular degeneration, congenital deafness

\section{INTRODUCTION}

Spiral ganglion cells (SGCs) reside in Rosenthal's canal (RC) of the cochlea. Their peripheral processes innervate the hair cell receptors, and their central processes conduct auditory information to the brain (Kiang et al. 1982). The survival of these neurons has been considered to be dependent upon the health of the organ of Corti as ganglion neurons undergo degenerative changes associated with hair cell damage and sensorineural hearing loss (Webster and Webster 1981; Spoendlin 1984; Leake and Hradek 1988; Rubel et al. 1990; Hardie and Shepherd 1999; Shepherd et al. 2006). Since cochlear implants bypass nonfunctioning receptor cells and target ganglion neurons for stimulation, spiral ganglion neuronal survival should be crucial for beneficial outcomes. Surprisingly, studies of human temporal bones from deceased cochlear implant recipients have reported 
no correlation between spiral ganglion cell loss and performance on speech recognition tasks (Nadol et al. 2001; Khan et al. 2005a, b; Fayad and Linthicum 2006). Despite advances in digital technology, processing software, and surgical methods, clinical studies still indicate a wide range in performance outcomes for implant users (Waltzman 2006).

Numerous variables (including etiology and duration of deafness, age at implantation, and extent of prior auditory experience) are known to influence clinical outcomes, thereby emphasizing the multifactorial nature of auditory performance following cochlear implantation. Yet the exact contribution of the total number of spiral ganglion cells to auditory performance remains unclear (Otte et al. 1978; Fayad and Linthicum 2006). In light of the fact that more than 120,000 individuals worldwide have received cochlear implants for the treatment of profound sensorineural hearing impairment (Wilson and Dorman 2008), clarification of the relationship between electrical stimulation of the cochlea and spiral ganglion cell viability is of paramount significance.

Several studies have addressed the issue of structural and functional consequences of auditory deprivation and the effects of intracochlear electrical stimulation on spiral ganglion cells (Lousteau 1987; Leake et al. 1991, 1999, 2008; Leake and Rebscher 2004; Li et al. 1999; Shepherd et al. 1994). In studies employing an ototoxic model of hearing loss, cats or guinea pigs are deafened as neonates by ototoxic drug administration (Webster and Webster 1981; Leake and Hradek 1988; Shepherd and Martin 1995). These drugs include aminoglycoside antibiotics (amikacin, neomycin, and kanamycin), salicylates, antineoplastics (cisplatin), and diuretics (ethacrynic acid and furosemide) and are known to cause loss of hair cell receptors in the inner ear (Hawkins 1973; Anniko 1985; Leake and Hradek 1988; Lustig et al. 1994; Shepherd and Hardie 2001).

Some in vivo results in ototoxically deafened cats and guinea pigs report that electrical stimulation increases ganglion cell density (e.g., Lousteau 1987; Hartshorn et al. 1991; Leake et al. 1991, 1999; Mitchell et al. 1997) and led to the interpretation that there is a beneficial effect on ganglion cell survival. It is important to note that there is a difference between ganglion cell density and total ganglion cell number because one parameter is not necessarily linked to the other. Specifically, it was reported that electrical stimulation was associated with a narrowing of Rosenthal's canal on the implanted side, thereby increasing ganglion cell density, but with no effect on overall ganglion cell survival (Li et al. 1999). In addition, there are reports that chronic electrical stimulation has no effect on spiral ganglion cell density (Araki et al. 1998, 2000; Coco et al. 2007).
The congenitally deaf white cat represents an alternative model and offers a naturally occurring form of deafness that is hereditary in nature (Mair 1973). There have been no reports addressing the effects of electrical stimulation on spiral ganglion cells with hereditary deafness, a form of hearing loss observed in humans. As a result, we used the congenitally deaf white cat to explore the neurotrophic effects of electrical stimulation on promoting spiral ganglion survival. Deaf white cats exhibit a type of deafness attributable to cochleosaccular degeneration that mimics the Scheibe deformity seen in humans. In the present experiments, congenitally deaf white cats were surgically implanted with cochlear implants and electrically stimulated for an average period of just over 2 months, after which spiral ganglion cells were examined. We hypothesized that the implanted cochleae (in comparison to cochleae of non-implanted deaf cats or cochleae contralateral to implants) would exhibit greater spiral ganglion neuronal survival (as measured by cell density and/ or cell count) and healthier ganglion neurons (as measured by somatic size) in response to electrical stimulation.

\section{MATERIALS AND METHODS}

\section{Experimental groups}

We analyzed data from 18 cats, aged 3 months to 3 years, for this study (Table 1 ). Three normal-hearing cats (one white and two pigmented), seven congenitally deaf white cats, and eight congenitally deaf white cats with unilateral cochlear implants were used. The implanted cats have contributed unrelated data to other studies (Kretzmer et al. 2004; Ryugo et al. 2005; O'Neil et al. 2010). Spiral ganglion cell counts were also used from cats whose numbers were previously published by others $(n=4$, Howe 1934; $n=1$, Gacek and Rasmussen 1961; $n=54$, Mair 1973). All procedures were conducted in accordance to NIH guidelines and were approved by the Johns Hopkins University Animal Care and Use Committee.

\section{Hearing assessment}

Because not all white cats are born deaf, each kitten was assessed at 30 days of age when hearing has begun to stabilize in the normal cat. Anesthetized kittens $(0.5 \mathrm{mg} / \mathrm{kg}$ xylazine and $0.1-0.24 \mathrm{mg} / \mathrm{kg}$ ketamine hydrochloride, IP) had recording electrodes inserted caudal and rostral to the pinna on both sides, and a grounding electrode was inserted in the neck. Differential potentials were measured across each pinna with reference to the ground. Sounds were presented at increasing levels through a free-field speaker 


\begin{tabular}{|c|c|c|c|c|c|c|}
\hline \multicolumn{7}{|c|}{ TABLE 1} \\
\hline \multicolumn{7}{|c|}{ Subjects } \\
\hline Cat ID & $\begin{array}{l}\text { Implant } \\
\text { age (days) }\end{array}$ & $\begin{array}{l}\text { Activation } \\
\text { age (days) }\end{array}$ & $\begin{array}{l}\text { Terminal } \\
\text { age (months) }\end{array}$ & $\begin{array}{l}\text { Amount of } \\
\text { stimulation (hours) }\end{array}$ & $\begin{array}{l}\text { Number a } \\
\text { ctive leads }\end{array}$ & PSD data ${ }^{a}$ \\
\hline \multicolumn{7}{|c|}{ Normal-hearing cats } \\
\hline PK90-1 & - & - & 3 & 0 & - & $x$ \\
\hline PK120-2 & - & - & 4 & 0 & - & No \\
\hline PK180-1 & - & - & 6 & 0 & - & No \\
\hline HWC04-016 & - & - & 6 & 0 & - & $x$ \\
\hline \multicolumn{7}{|c|}{ Congenitally deaf cats } \\
\hline DWK90-3 & - & - & 3 & 0 & 0 & No \\
\hline DWK04-109 & - & - & 3 & 0 & 0 & No \\
\hline DWK120-2 & - & - & 4 & 0 & 0 & No \\
\hline DWK150-1 & - & - & 5 & 0 & 0 & No \\
\hline DWK180-5 & - & - & 6 & 0 & 0 & $x$ \\
\hline DWC04-112 & - & - & 12 & 0 & 0 & no \\
\hline DWC02-104 & - & - & 36 & 0 & 0 & no \\
\hline \multicolumn{7}{|c|}{ Cochlear implant cats } \\
\hline CIK-1 & 93 & 116 & 6 & 510 & 5 & $x$ \\
\hline CIK-2 & 75 & 97 & 6 & 330 & 6 & $x$ \\
\hline CIK-3 & 97 & 128 & 6 & 781 & 3 & $x$ \\
\hline CIK-4 & 173 & 192 & 9 & 552 & 3 & $x$ \\
\hline CIK-5 & 163 & 193 & 9 & 584 & 4 & $x$ \\
\hline CIK-6 & 90 & 122 & 6 & 958 & 3 & $x$ \\
\hline CIK-8 & 95 & 105 & 6 & 522 & 4 & $x$ \\
\hline CIK-7 & 89 & Failed & 6 & 0 & 0 & $\mathrm{x}$ \\
\hline Non-activated & & & & & & \\
\hline
\end{tabular}

Not all cats contributed equal amounts of data

${ }^{\mathrm{a}} \mathrm{O}^{\prime}$ Neil et al. 2010

(Radio Shack, Fort Worth, Texas), and evoked responses were averaged over 1,000 stimulus presentations. Profoundly deaf cats were identified and selected by absent auditory brainstem response (ABR) to tones that reached 95-dB SPL (re 0.0002 dynes per square centimeter) as measured by a calibrating microphone. Standard protocols for ABR testing (e.g., Ryugo et al. 1997, 2003) were implemented in Matlab (MathWorks, Natick, Massachusetts) on Tucker-Davis hardware (Alachua, Florida).

\section{Cochlear implants}

Bilaterally deaf kittens were surgically fitted on the left side with a six-electrode, unilateral cochlear implant (Advanced Bionics Corp., Sylmar, CA) containing a Clarion II type receiver with custom electrode at 3 months $(n=6)$ or 6 months $(n=2)$ of age. Radiographic analysis confirmed that the 6-mm electrode array was within the cochlea with the last (sixth) electrode near the round window. Based on the length of typical cat cochleae, the electrodes were calculated to be situated along the basal $25 \%$ of the cochlea, a region sensitive to frequencies of $13 \mathrm{kHz}$ and higher (Liberman and Mulroy 1982). The ages for surgery, cochlear implant activation, and termination for each subject are listed in Table 1. At activation, functional electrodes had relatively low impedances and were identified by behavioral cues (pupil dilation and pinna flicks) and electrically evoked cochlear potentials. At least two electrodes were functional in each cat's stimulation program.

Sound was detected by a microphone and delivered to a sound processor (Advanced Bionics Corporation, Sylmar, CA) where signals were translated into electrical impulses at each electrode in the cochlea. The stimulation paradigm was a modification of the CIS strategy using $>3,000-\mathrm{Hz}$ carrier rate. Biphasic pulses were amplitude-modulated by band-pass filtering and distributed across the active electrodes (Advanced Bionics, HiRes); electrodes were activated in a monopolar configuration. Cats wore the processor approximately 5 days a week for $7 \mathrm{~h}$ each day. In addition to passive listening, cats learned to approach a speaker in response to a specific sound that was consistently paired with food. They also interacted with lab personnel during the day and were handled and exposed to a variety of other environmental sounds.

\section{Tissue preparation}

At the end of the stimulation period, the cats were euthanized by administration of a lethal dose of sodium pentobarbital. Once fully anesthetized, cats were administered the anticoagulant heparin and 
perfused through the heart with $50 \mathrm{~cm}^{3}$ of $0.1 \mathrm{M}$ phosphate-buffered saline containing a vasodilator $(0.1 \%$ sodium nitrite), followed immediately by $2 \mathrm{~L}$ of a standard fixative solution (2\% glutaraldehyde, $2 \%$ paraformaldehyde in $0.1 \mathrm{M}$ phosphate buffer, $\mathrm{pH}$ 7.4).

After removal of the implant processor, the cranium was opened, and each cochlea was perfused through the round and oval windows with $1 \%$ solution of $\mathrm{OsO}_{4}$ in $S$-collidine buffer (pH 7.2). After $15 \mathrm{~min}$, the cochlea was perfused with the standard fixative to remove the $\mathrm{OsO}_{4}$. The following day, the cochleae were dissected free of the skull and placed in a solution of neutral buffered $0.1 \mathrm{M}$ ethylenediaminetetraacetic acid (EDTA) with 1\% glutaraldehyde and $1 \%$ paraformaldehyde. The EDTA solution was changed daily, and the cochleae were agitated on a shaker. After decalcification, the cochleae from all animals except one were prepared for Araldite embedding and cut at $20-\mu \mathrm{m}$ thickness on a rotary microtome. One cochlear pair was infiltrated with a solution of gelatin and albumin, hardened with glutaraldehyde, and cut at $40 \mu \mathrm{m}$ using a Vibratome. Cochleae were sectioned parallel to the modiolus and in a nearly horizontal plane. All Vibratome sections were stained with cresyl violet and every fifth Araldite section was stained by toluidine blue. Sections were then mounted in glass microscope slides and coverslipped in Permount for observation under the light microscope. Due to technical difficulties, some sections from the right cochleae of cats CIK-3, CIK-4, and CIK- 6 were lost. Because we kept track of the number of sections taken, we could calculate the lengths of what was missing to obtain length values for Rosenthal's canal (Table 2). We were, however, unable to estimate the number of spiral ganglion cells that were or were not present because cell loss is not predictable in congenitally deaf cats (Table 3). Since we observed that there was no statistical difference in spiral ganglion cell size with respect to cochlear position, we could collect cell body size in a random fashion from those sections that remained (Table 4).

\section{Light microscopy and 3-D reconstruction} of the spiral ganglia

Every fifth section (100- $\mu \mathrm{m}$ separation) was aligned to its nearest neighbor using the basilar membrane, scalae, Rosenthal's canal, and boundary of the otic capsule as reference points to achieve a "best fit" as defined by a smooth trajectory of Rosenthal's canal from the base to apex (see Fig. 1). Approximately 30 sections were used for each reconstruction. The length of each spiral ganglion was graphically reconstructed using a combination of Neurolucida, version
7.50.4 (MicroBrightField, Inc., Williston, Vermont), and Amira, version 4.50.4 (Visage Imaging, Carlsbad, California). The reconstructed lengths were measured using Amira's SplineProbe functionality (Fig. 1A). Segments of bone contained within RC were also traced, and their areas subtracted from the overall $\mathrm{RC}$ area per section. The spiral ganglion of each cochlea was divided into $10 \%$ intervals along its length in order to provide a means of normalizing the collected data. An average of three sections per percent interval was then selected for further spiral ganglion cells density and soma area analysis (Fig. 1B). By limiting the sampling to restricted regions at $10 \%$ intervals, the number of cells drawn and counted varied from section to section and from cat to cat. Individual type I SGCs were drawn using an oil immersion $\times 100$ objective lens (N.A. 1.3), and only those cells containing prominent nucleoli were included in this analysis. Because a single nucleolus (approximately $2 \mu \mathrm{m}$ in diameter) could not meet criterion for counting in two adjacent sections, it may be considered a point source and provides an estimate that needs no corrections (Guillery 2002). We counted and measured between 11 and 338 type I spiral ganglion cells per section and between 560 and 1,169 cells per sampling region. SGC density was calculated as total SGC count divided by the total area of Rosenthal's canal per section and presented as number of cells per 0.01 units of normalized length. The number of ganglion cells for each $10 \%$ interval was determined by multiplying the density per region by 10 to yield the number of ganglion cells per interval; the values for each of the 10 intervals were then summed to yield a total number of ganglion cells per cochlea. The areas of SGC somata were measured using NIH ImageJ, v. 1.40 .

\section{Data analysis}

Values for ganglion cell features were compared between left and right sides within individuals. If there was no difference between sides, each side could be treated independently and grouped into a cohort for data analysis. Separate cohorts were defined that utilized data collected from the cochleae of normal-hearing cats, congenitally deaf cats, the ipsilateral side of congenitally deaf cats with a unilateral cochlear implant, and the contralateral side of deaf cats with a cochlear implant. Mean and standard deviation values are provided in the text and tables. We applied multivariable analysis of variance (ANOVA) and Tukey-Kramer honestly significant difference (HSD) tests where appropriate. These tests incorporate the Bonferroni adjustment for multiple comparison procedures. 
TABLE 2

\begin{tabular}{|c|c|c|c|}
\hline \multicolumn{4}{|c|}{ Rosenthal's canal lengths } \\
\hline Cohort & Left ganglion length $(\mathrm{mm})$ & Right ganglion length (mm) & Average ganglion length $(\mathrm{mm}) \pm S D$ \\
\hline \multicolumn{4}{|l|}{ Normal hearing } \\
\hline PK180-1 & 12.1236 & 12.2485 & $11.9 \pm 0.56 \mathrm{~mm}$ \\
\hline HWC04-015 & 11.2175 & - & \\
\hline \multicolumn{4}{|l|}{ Congenitally deaf } \\
\hline DWK120-2 & - & 12.6704 & $11.6 \pm 0.98 \mathrm{~mm}$ \\
\hline DWK180-5 & 11.2005 & - & \\
\hline DWC04-112 & 10.4556 & - & \\
\hline DWC02-104 & 12.1281 & - & \\
\hline Cochlear implant & Ipsilateral & Contralateral & \\
\hline CIK-1 & 7.0619 & 9.9048 & Left $=9.5 \pm 1.5 \mathrm{~mm}$ \\
\hline CIK-2 & 10.6882 & 11.2950 & \\
\hline CIK-3 & 11.1826 & 9.9129 & Right $=10.0 \pm 1.0 \mathrm{~mm}$ \\
\hline CIK-4 & 9.4299 & 9.8447 & \\
\hline CIK-5 & 8.8668 & 7.8673 & All: $9.8 \pm 1.25$ \\
\hline CIK-6 & 10.0744 & 10.8634 & \\
\hline CIK-7 & 8.1178 & 10.7349 & \\
\hline CIK-8 & 10.9075 & 10.0243 & \\
\hline
\end{tabular}

The left ear was implanted for all cats. There is no significant difference in canal lengths when comparing the implanted (left) and unimplanted (right) cochleae for the implanted cats $(p=0.12)$. The implanted cats, however, exhibit a shorter canal length compared to normal-hearing and unimplanted congenitally deaf cats $(p<0.01$, Tukey-Kramer HSD)

\begin{tabular}{|c|c|c|c|c|}
\hline \multicolumn{5}{|c|}{ TABLE 3} \\
\hline \multicolumn{5}{|c|}{ Spiral ganglion cell counts } \\
\hline Cat & Status & Age & Left & Right \\
\hline \multicolumn{5}{|l|}{ Normal-hearing cats } \\
\hline PK120-2 & Normal pigmented & 4 months & - & 49,175 \\
\hline PK180-1 & Normal pigmented & 6 months & 47,588 & 50,109 \\
\hline \multirow[t]{3}{*}{ Howe (1934) } & Cat N2 & Adult & 45,894 & 44,298 \\
\hline & Cat N4 & Adult & 55,584 & 51,594 \\
\hline & Cat N5 & Adult & 57,494 & 48,487 \\
\hline Gacek and Rasmussen (1961) & Cat C-1 & Adult & 53,649 & 49,500 \\
\hline \multicolumn{5}{|l|}{ Deaf white cats } \\
\hline \multirow[t]{8}{*}{ Mair 1973} & Astyanax & 12 days & 46,873 & 47,898 \\
\hline & Ino & 43 days & 44,355 & 46,079 \\
\hline & Pelias & 47 days & 45,951 & 48,117 \\
\hline & Cleo & 2 months & 50,055 & 50,483 \\
\hline & Hector & 6 months & 52,240 & 54,482 \\
\hline & Ulysses & 10 months & 44,726 & 45,951 \\
\hline & Aphrodite & 21 months & 33,530 & 32,010 \\
\hline & Eva & 22 months & 17,404 & 15,751 \\
\hline DWK90-3 & Deaf & 3 months & 46,150 & 48,880 \\
\hline DWK120-2 & Deaf & 4 months & 44,560 & 41,850 \\
\hline DWK180-5 & Deaf & 6 months & 43,664 & 35,604 \\
\hline DWC04-112 & Deaf & 12 months & - & 38,699 \\
\hline DWC02-104 & Deaf & 36 months & 28,400 & - \\
\hline \multicolumn{3}{|l|}{ Cochlear-implanted cats } & Ipsilateral & Contralateral \\
\hline CIK-1 & Early implant & 6 months & 26,130 & 48,192 \\
\hline CIK-2 & Early implant & 6 months & 40,384 & 31,266 \\
\hline CIK-3 & Early implant & 6 months & 11,090 & - \\
\hline CIK-4 & Late implant & 9 months & 27,352 & - \\
\hline CIK-5 & Late implant & 9 months & 20,484 & 30,580 \\
\hline CIK-6 & Early Implant & 6 months & 24,739 & - \\
\hline CIK-7 & Failed Implant & 6 months & 30,466 & 35,770 \\
\hline CIK-8 & Early Implant & 6 months & 33,878 & 28,620 \\
\hline
\end{tabular}

In cats where total, bilateral ganglion cell counts were possible, comparison between left and right sides revealed no significant difference for normal, deaf white, and cochlear-implanted cats (ANOVA, $p=0.513$ ) 
TABLE 4

\begin{tabular}{|c|c|c|c|c|c|c|}
\hline \multicolumn{7}{|c|}{ Spiral ganglion cell body size } \\
\hline Cat ID & Status & $\begin{array}{l}\text { Age at death } \\
\text { (months) }\end{array}$ & $\begin{array}{l}\text { Embedding medium } \\
\text { and thickness }\end{array}$ & SGC size left & SGC size right & $L-R$ diff \\
\hline \multicolumn{7}{|l|}{ Normal-hearing cats } \\
\hline PK90-1 & Normal & 3 & Araldite $20 \mu \mathrm{m}$ & $239.7 \pm 46.5 n=152$ & $237.3 \pm 44.8 n=131$ & NS \\
\hline PK180-1 & Normal & 6 & Araldite $20 \mu \mathrm{m}$ & $228.9 \pm 51.0 n=749$ & $197.3 \pm 43.9 n=1,456$ & $\mathrm{~L}$ \\
\hline \multicolumn{7}{|l|}{ Deaf white cats } \\
\hline DWK90-3 & Deaf & 3 & Araldite $20 \mu \mathrm{m}$ & $167.2 \pm 28.9 n=527$ & $164.5 \pm 28.4 n=143$ & NS \\
\hline DWK04-109 & Deaf & 3 & Araldite $20 \mu \mathrm{m}$ & $168.9 \pm 33.4 n=175$ & $165.7 \pm 31.1 n=176$ & NS \\
\hline DWK120-2 & Deaf & 4 & Araldite $20 \mu \mathrm{m}$ & $166.8 \pm 28.8 n=154$ & $171.9 \pm 26.1 n=189$ & NS \\
\hline DWK150-1 & Deaf & 5 & Araldite $20 \mu \mathrm{m}$ & $185.9 \pm 34.4 n=271$ & $190.4 \pm 38.5 n=123$ & NS \\
\hline DWK180-5 & Deaf & 6 & Araldite $20 \mu \mathrm{m}$ & $150.0 \pm 21.6 n=156$ & $148.7 \pm 28.6 n=233$ & NS \\
\hline Cochlear-implanted cats & & & & Ipsilateral & Contralateral & \\
\hline CIK-1 & 3-month implant & $6 \mathrm{mo}$ & Araldite $20 \mu \mathrm{m}$ & $112.6 \pm 49.5 n=187$ & $210.1 \pm 29.7 n=383$ & $\mathrm{R}$ \\
\hline CIK-2 & 3-month implant & $6 \mathrm{mo}$ & Araldite $20 \mu \mathrm{m}$ & $142.8 \pm 31.4 n=685$ & $149.1 \pm 23.6 n=260$ & NS \\
\hline CIK-3 & 3-month implant & $6 \mathrm{mo}$ & Gelatin $40 \mu \mathrm{m}$ & $168.7 \pm 35.9 n=348$ & $124.1 \pm 27.1 n=230$ & $\mathrm{~L}$ \\
\hline CIK-4 & 6-month implant & 9 mo & Araldite $20 \mu \mathrm{m}$ & $177.5 \pm 46.3 n=413$ & $122.0 \pm 23.4 n=332$ & $\mathrm{~L}$ \\
\hline CIK-5 & 6-month implant & $9 \mathrm{mo}$ & Araldite $20 \mu \mathrm{m}$ & $75.9 \pm 16.2 n=155$ & $107.4 \pm 18.9 n=196$ & $\mathrm{R}$ \\
\hline CIK-6 & 3-month implant & $6 \mathrm{mo}$ & Araldite $20 \mu \mathrm{m}$ & $183.4 \pm 44.1 n=377$ & $244.4 \pm 50.7 n=280$ & $\mathrm{R}$ \\
\hline CIK-7 & Device failure & $6 \mathrm{mo}$ & Araldite $20 \mu \mathrm{m}$ & $166.0 \pm 31.3 n=652$ & $206.8 \pm 33.9 n=460$ & $\mathrm{R}$ \\
\hline CIK-8 & 3-month implant & $6 \mathrm{mo}$ & Araldite $20 \mu \mathrm{m}$ & $142.7 \pm 31.7 n=607$ & $166.7 \pm 26.6 n=156$ & $\mathrm{R}$ \\
\hline
\end{tabular}

In the case of cochlear-implanted cats, there were differences in cell body size but these were not related to side of implantation (binominal sign test, $p=0.226$ )

NS no difference between the left and right sides for cell body size within individual cats

\section{RESULTS}

\section{Cochlear implants and electrical stimulation}

The experimental design was set to begin "early" stimulation at 3 months of age (range 2.5-3.2 months) and "late" stimulation at 6 months of age (range 5.35.7 months). Actual surgical implantation had to be scheduled around weekends, holidays, and health of the animal, and activation times had to be adjusted on a cat-by-cat basis due to variations in post-implant recovery rate. The "early" group was activated at an average age of $3.8 \pm 0.42$ months, whereas the "late" group was activated at $6.3 \pm 0.02$ months. Each cat received just over 2 months of stimulation via its cochlear implant. Total stimulation time varied from 330 to $958 \mathrm{~h}$ for those cats whose devices were functional (Table 1). It should be noted that period of stimulation, number of active electrode leads, and total hours of stimulation were not crucial variables in these results (see below).

\section{Organ of Corti}

All congenitally deaf white cats, including those with unilateral cochlear implants, displayed bilateral degeneration in the organ of Corti through all turns. The Scheibe-like dysplasia is characterized by an obliterated scala media as Reissner's membrane drapes over the surface of the stria vascularis, drops onto the exposed surface of the organ of Corti, and compresses the tectorial membrane (Scheibe 1892; Elverland and Mair 1980; Schuknecht 1993). This pattern of collapse typically begins after the first postnatal week (Mair 1973) and has been recently confirmed in an independent colony of congenitally deaf white cats (Baker et al. 2010). The organ of Corti is reduced to an undifferentiated mass of cells where hair cells, usually typified by their location and apical tuft of stereocilia, are completely absent in the adult (Fig. 2). This lack of hair cells and the histologic disorganization of the organ of Corti were consistent with absent auditory responses seen in profound deafness (Ryugo et al. 1997, 1998, 2003). The timing of this collapse occurs well before the onset of hearing, affirming that these cats do not hear.

\section{Vestibular epithelia}

Hereditary deafness in the white cat has been described as cochleosaccular degeneration (Mair 1973). In our colony, the deaf white cats did not exhibit balance or motor abnormalities. Consequently, the vestibular apparatus was usually drilled away to expedite cochlear processing. In cases where care was taken to dissect and histologically prepare vestibular structures in the implanted cats, the utricle and cristae epithelia showed no evidence of "missing hair cells," and those hair cells that were present were organized in an orderly fashion. There were also instances in which the saccule also appeared intact and exhibited normal hair bundles, received myelinated afferent fibers, and possessed remnants of otoconia (Fig. 3). In other instances, the membranous labyrinth was collapsed over the saccule. Unfortunately, 


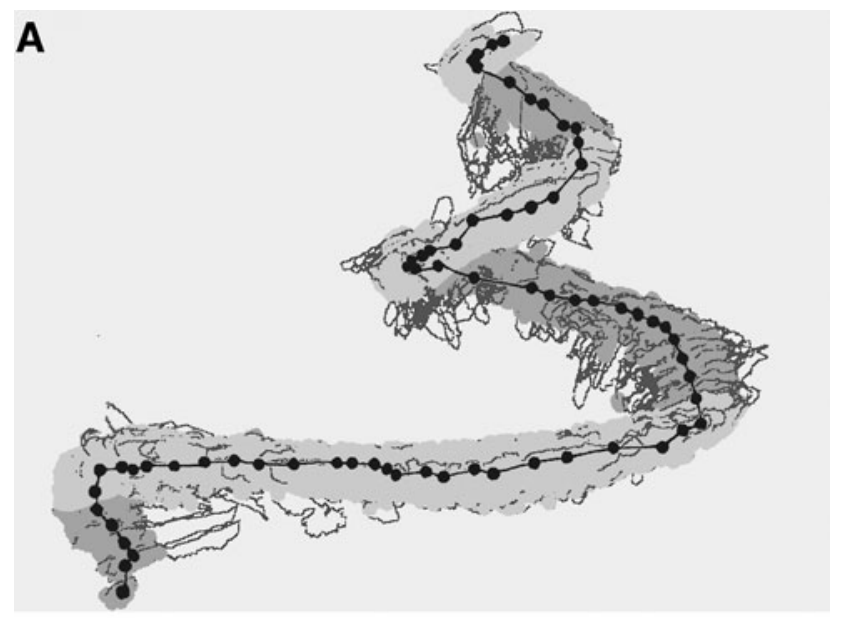

B

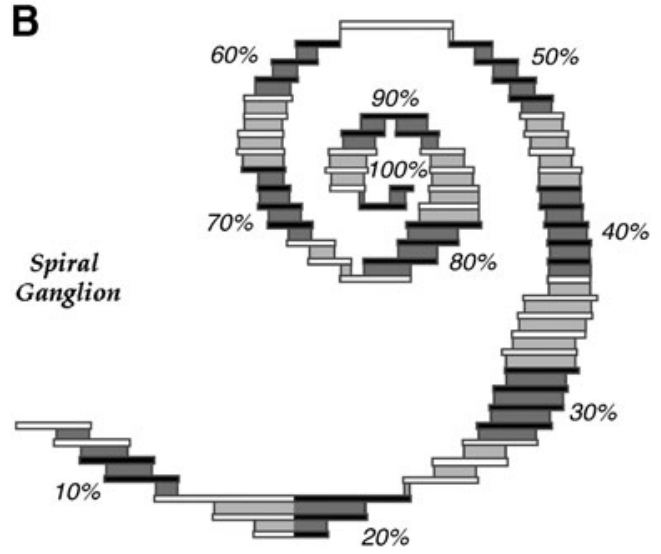

$\overline{-1}$

Section number:

FIG. 1. Three-dimensional reconstruction of Rosenthal's canal of a normal-hearing cat. A Rosenthal's canal (gray) shown after being rendered in 3-D using Amira software. The dots are in the approximate center of the canal for each section. The lines connecting each dot were measured, and the sum of the lines represents the length of the canal. B Rosenthal's canal (spiral ganglion) is rotated so that the view looks down the modiolus from the apex of the cochlea. The section number through the cochlea is shown on the right. The length of the ganglion is parsed into $10 \%$ intervals from base to apex. The darker segments are where ganglion cell measurement and counts were made.

we did not have sufficient vestibular end organ morphology or quantitative behavioral data to draw reliable conclusions.

\section{Osseous spiral lamina}

Accompanying the loss of the organ of Corti, pathological changes were also observed in primary auditory neurons. There is partial loss of the myelinated peripheral processes along the osseous spiral lamina that occurs with degeneration of spiral ganglion cell bodies. In stark contrast to the complete loss of peripheral processes in normal-hearing kittens deafened via

ototoxic agents (Terayama et al. 1977; Shepherd and Hardie 2001), myelinated peripheral processes in our hereditary deaf cats can be observed in our cochlear-implanted cats and in unimplanted congenitally deaf cats up to a year in age (Fig. 4, asterisks). The degree of myelinated fiber survival, however, was variable, and the tissue was not prepared in such a way as to permit quantitative assessments of peripheral process survival.

\section{Scar tissue}

The electrode array of the cochlear implant was inserted into the scala tympani from the round window. The final position of the electrode was inferred by the presence of fibrosis and ossification (Fig. 5). Such tissue reaction was only found in the basal turn of the cochlea on the implanted side, but because we removed the electrodes prior to histologic processing, we do not have direct evidence of scar formation around the electrodes. In six of eight cases, the electrode seemed to remain lodged in the scala tympani because scar formation was restricted to this intracochlear compartment. In two other cases, the
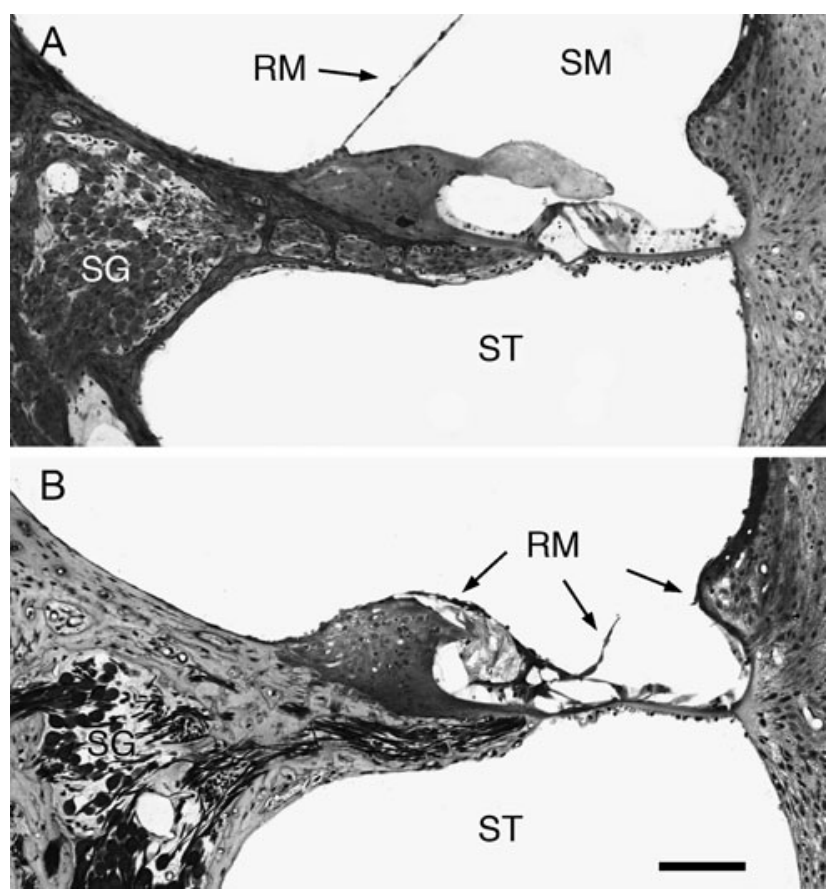

FIG. 2. Photomicrographs through basal turn of the organ of Corti. A Organ of Corti of normal-hearing cat with major components present, including the three rows of hair cell receptors, supporting cells, and tectorial membrane. Reissner's membrane $(R M)$ is intact. B Organ of Corti is missing in a cochlear-implanted, congenitally deaf white cat. Reissner's membrane $(R M)$ has collapsed over the spiral limbus, tectorial membrane, and organ of Corti, obliterating scala media. There is loss of spiral ganglion cells but a substantial number of osmium-stained myelinated fibers remain. Scale bar equals $100 \mu \mathrm{m}$. 


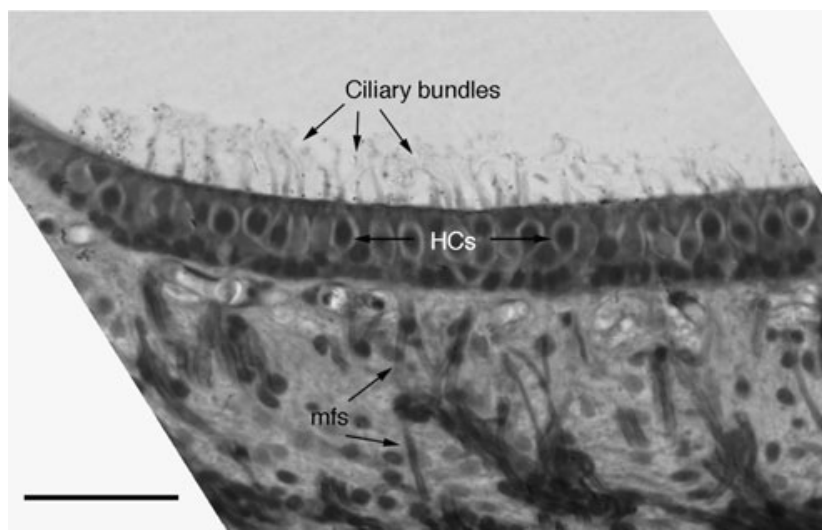

FIG. 3. Histologic section through the saccular macula of a deaf white cat. The hair cells (HCs) and ciliary hair bundles are evident, along with the myelinated afferents $(m f s)$ that innervate the hair cells. The otoconia membrane was washed away during processing. Scale bar equals $50 \mu \mathrm{m}$.

basilar membrane was disrupted, and localized fibrosis was also observed in the scala vestibuli. Scars were created when electrodes were surgically implanted at 3 or 6 months of age, and they varied greatly in appearance. Regardless of its location, the scar could
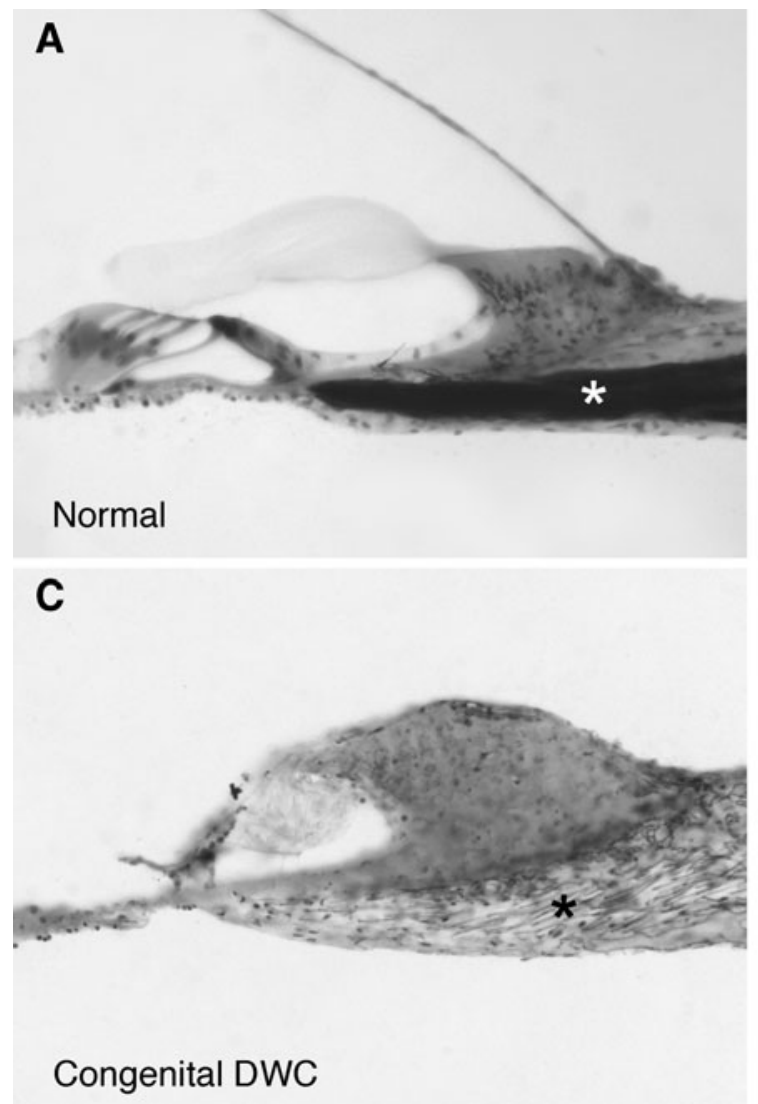

FIG. 4. Photomicrographs of the osseous spiral lamina in the middle turn of a normal-hearing cat (A), congenitally deaf cat with a cochlear implant (B, D), and a congenitally deaf cat $(\mathbf{C})$. This figure shows the collapsed Reissner's membrane $(\mathbf{B}, \mathbf{C}, \mathbf{D})$ that flattens the appear as mostly fibrous tissue (Fig. 5A), a composite of bone and cartilage (Fig. 5B), or as a mixture of bone, cartilage, and connective tissue (Fig. 5C). The type or size of the scar appeared unrelated to electrode thresholds, the relative survival of spiral ganglion cells, or the magnitude of synaptic restoration in auditory nerve terminals in the cochlear nucleus.

\section{Spiral ganglion}

\section{Spiral ganglion length}

Primary auditory neurons that innervate the hair cell receptors reside in Rosenthal's canal of the cochlea (Fig. 6). Rosenthal's canal is situated in porous bone that spirals around the modiolus, parallel to the cochlear spiral (e.g., Fig. 1), while the neurons form the spiral ganglion. The spiral ganglia from each cat were reconstructed in three dimensions using light microscopy and Amira software by measuring their lengths through a series of points at the center of Rosenthal's canal. The average length for normalhearing cats was $11.86 \pm 0.56 \mathrm{~mm}$, and for congenitally deaf cats, the average length was $11.61 \pm 0.98 \mathrm{~mm}$;

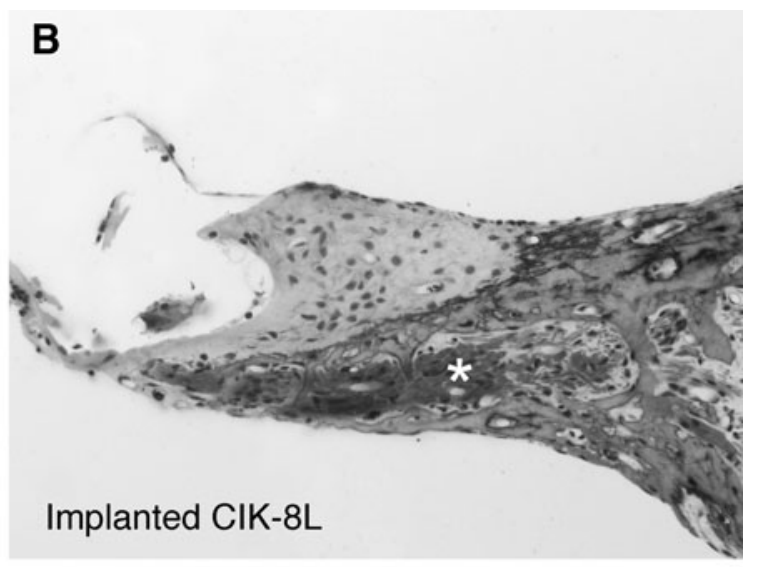

D

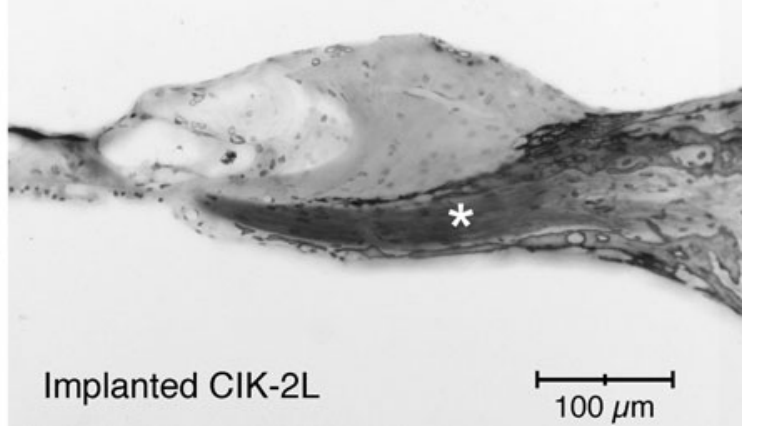

tectorial membrane and organ of Corti; it also shows that myelinated peripheral processes (asterisks) of spiral ganglion cells diminish but still exist in cats with inherited congenital deafness with and without a cochlear implant. Scale bar equals $100 \mu \mathrm{m}$. 

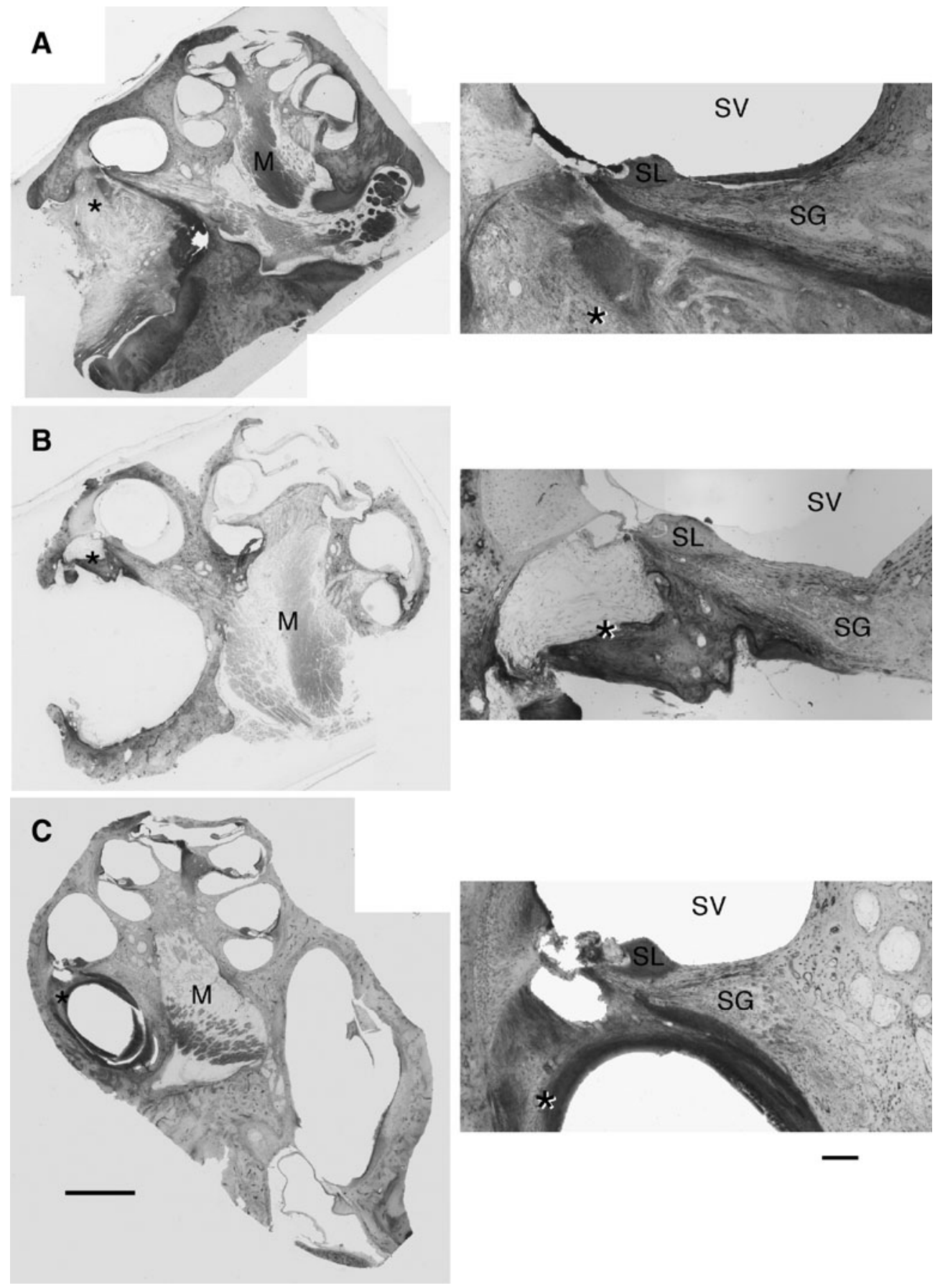

FIG. 5. Photomicrographs illustrating representative types of scar formation in response to cochlear implantation. A Fibrosis dominates this scar (asterisk) and fills nearly all of the scala vestibuli. B Bone and cartilage (asterisk) form this scar that adheres to the scala tympani side of the cochlear partition. $\mathbf{C}$ The electrode on this implant broke into the scala vestibuli through the cochlear partition. There is mostly bone growth along the underside of the osseous

there is no statistical difference between these values. Our results for normal-hearing cats are comparable to what has been previously reported (mean $12.5 \mathrm{~mm}$; range $10.1-14.8 \mathrm{~mm}$ for normal-hearing cats, Keithley and Schreiber 1987; mean $10.67 \pm 0.38 \mathrm{~mm}$; range

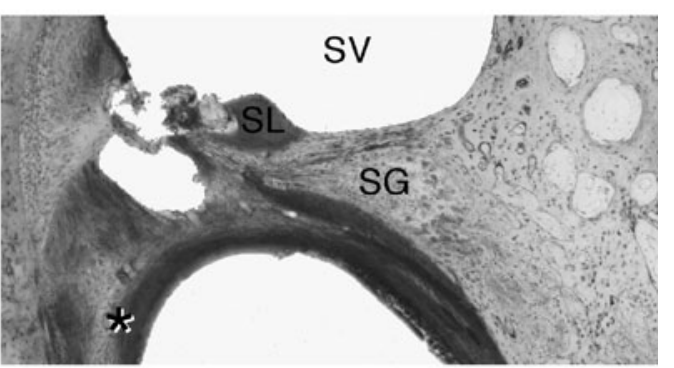

spiral lamina (asterisk) and cellular debris in the scala vestibuli. Each of these cochleae was associated with the restoration of auditory nerve synapses on spherical bushy cells in the cochlear nucleus (O'Neil et al. 2010). Abbreviations: $M$ modiolus, SG spiral ganglion, $S L$ spiral limbus, SV scala vestibuli. Scale bars equal $500 \mu \mathrm{m}$ (left) and $100 \mu \mathrm{m}$ (right).

10.3-11.6 $\mathrm{mm}$ for congenitally deaf white cats, Mair 1973). For implanted cats, the implanted side was $9.54 \pm$ $1.45 \mathrm{~mm}$, whereas the unimplanted side was $10.1 \pm$ $1.04 \mathrm{~mm}$ (Table 2). There is no significant difference in the lengths of Rosenthal's canal when comparing 

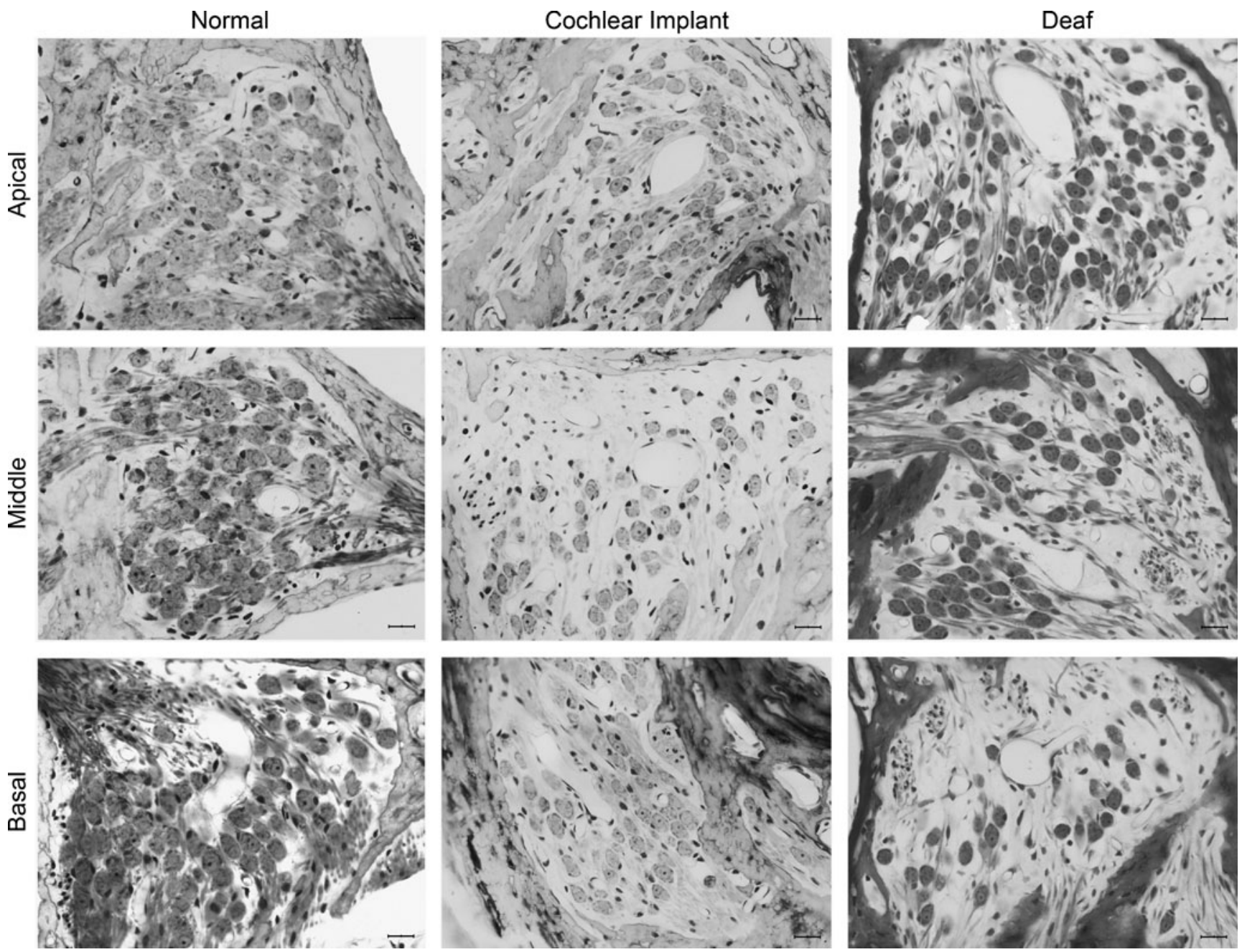

FIG. 6. Photomicrographs of the spiral ganglia of 6-month-old cats through the middle of each turn illustrating ganglion cell size, density, and the effects of congenital deafness and cochlear implantation. In general, deafness with or without electrical stimulation via a cochlear implant results in loss of size and number of

implanted and unimplanted cochleae of the same individual $(p>0.05)$, Tukey-Kramer HSD. The cochleae of implanted cats were, however, significantly shorter than those of unimplanted normal-hearing or congenitally deaf cats $(p<0.01$, Tukey-Kramer HSD).

\section{Spiral ganglion cell density}

Ganglion cell density was calculated by dividing the total number of ganglion cells counted in the three consecutive sections by the summed area of Rosenthal's canal. These data were averaged at $10 \%$ intervals from cochlear base to apex. No significant density difference was observed between the congenitally deaf and cochlear-implanted cats within the 0 $30 \%$ and $70-100 \%$ sections of the ganglion length (Fig. 7). Cochlear-implanted cohorts experienced density losses within the $30-70 \%$ intervals when compared to congenitally deaf ones, and both expe- primary neurons. There was no significant difference between the implanted and unimplanted deaf cats, but there were significant reductions of ganglion cell density when compared to normalhearing cats. Scale bar equals $20 \mu \mathrm{m}$.

rienced considerable density loss in comparison to normal-hearing cats within the $50-100 \%$ intervals. This effect, however, appeared unrelated to the spatial proximity of the electrode array (Fig. 7).

\section{Spiral ganglion cell number}

Using ganglion cell densities and Rosenthal's canal lengths, the numbers of ganglion cells were calculated. Normal-hearing cats (aged 6 days to adult) have on average the greatest number of spiral ganglion cells $(51,270 \pm 4,114, n=21$ cats, 27 cochleae) among the cohorts (Table 3). These counts included previously published data from 17 white cats with normal hearing (Mair 1973) and nine pigmented cats with normal hearing (Howe 1934). Deaf white cats between the ages of 6 and 10 months had an average of $47,370 \pm 6,490$ ganglion cells, which included previously published data from three deaf white cats 


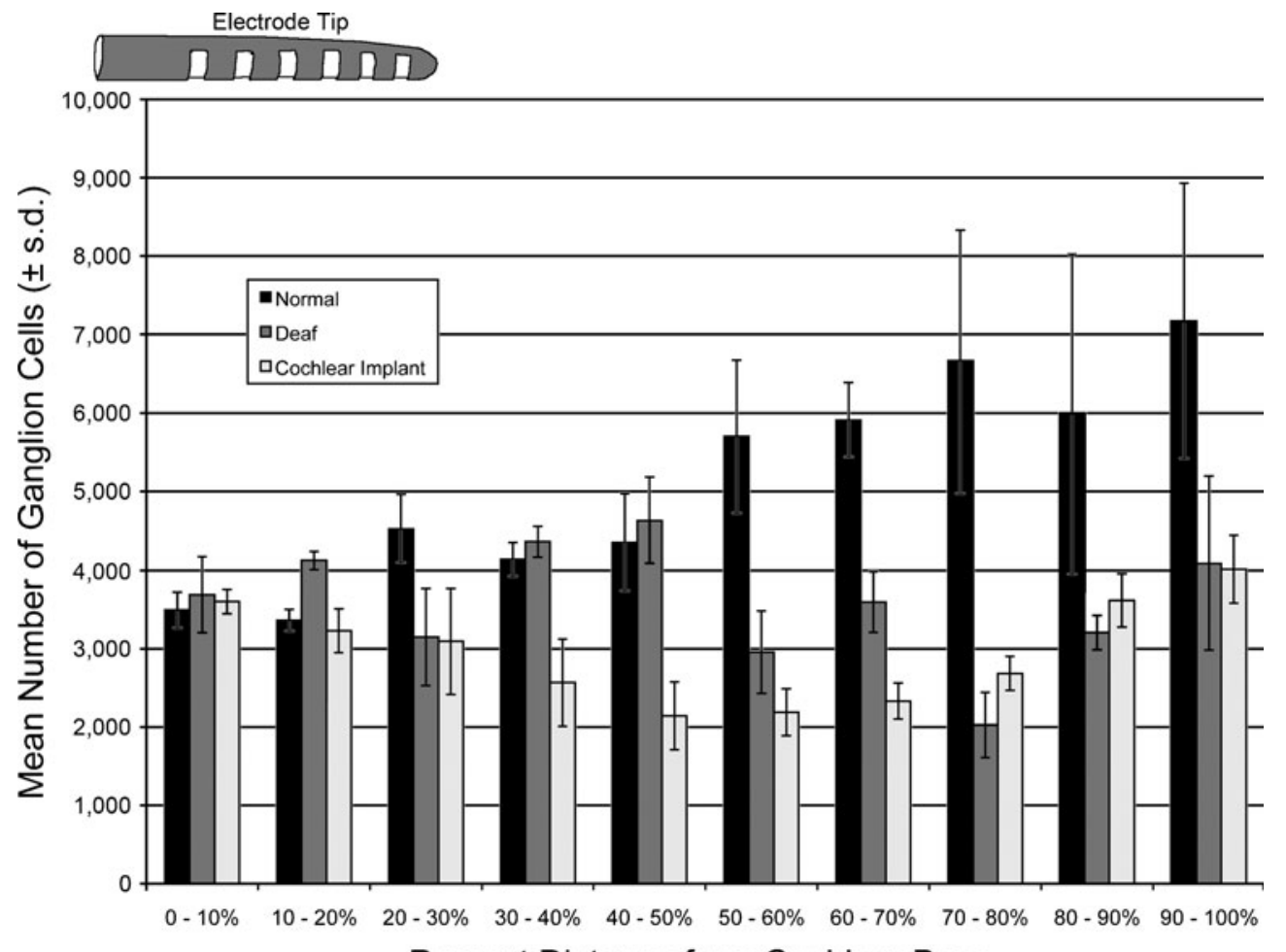

Percent Distance from Cochlear Base

FIG. 7. Bar graph illustrating the relationship of ganglion cell density with respect to the location of the cochlear implant electrode and normal hearing (black bars), congenitally deaf (gray bars), and congenitally deaf with cochlear implant (light bars). There is essentially no effect on cell density by electrical stimulation when compared to unimplanted congenitally deaf cats.

(Mair 1973). Deaf white cats with cochlear implants had the fewest spiral ganglion cells $(n=13$ cochleae, $29,919.3 \pm 9,078$ cells per cochlea) among the cohorts of normal-hearing cats, congenitally deaf cats, and the ipsilateral and contralateral cochleae of implanted cats. Although there was a numerical difference between the sides ipsilateral and contralateral to the cochlear implant, this difference was not statistically significant (Fig. 8, $p>0.05$, Tukey-Kramer HSD).

In situations where cochlear hair cells are absent or injured, primary neurons gradually die off and those that remain are smaller in size (Fig. 6). For the first 2 months of age, ganglion cell numbers remain relatively constant for normal-hearing and congenitally deaf white cats (Fig. 9). At 90 days of age, however, ganglion cell loss becomes apparent (Fig. 10). This is the age when our deaf cats received their cochlear implants and when ganglion features establish a baseline to compare the effects of implantation. The spiral ganglia of congenitally deaf cats exhibit on average a $13.7 \%$ reduction in cell number at this age.

\section{Spiral ganglion cell body size}

Ganglion cell size was represented by somatic silhouette area (Table 4). We drew and measured all ganglion cells that met nucleolar criteria in three consecutive sections at normalized $10 \%$ intervals from cochlear base to apex. No statistically significant difference in somatic size was observed between the congenitally deaf and cochlear-implanted subjects throughout the entire ganglion length, although

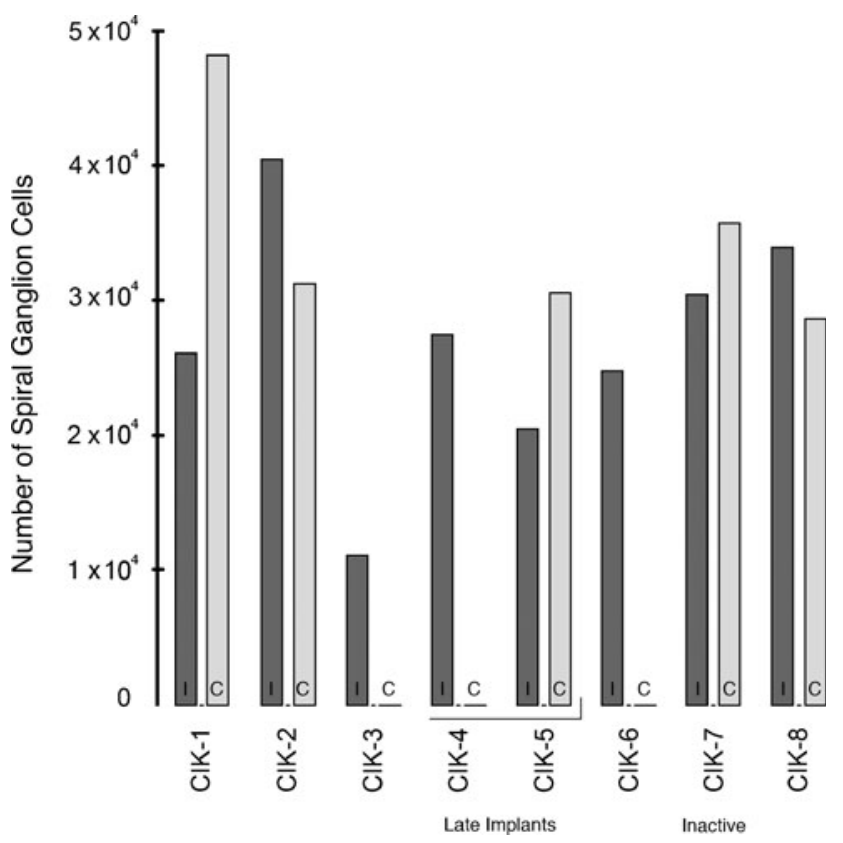

FIG. 8. Plot of ganglion cell number with respect to the side ipsilateral (dark bar) and contralateral (light bar) to the cochlear implant. On the basis of the binomial sign test, there is no effect of direct electrical stimulation for promoting ganglion cell survival $(p>0.05)$. 


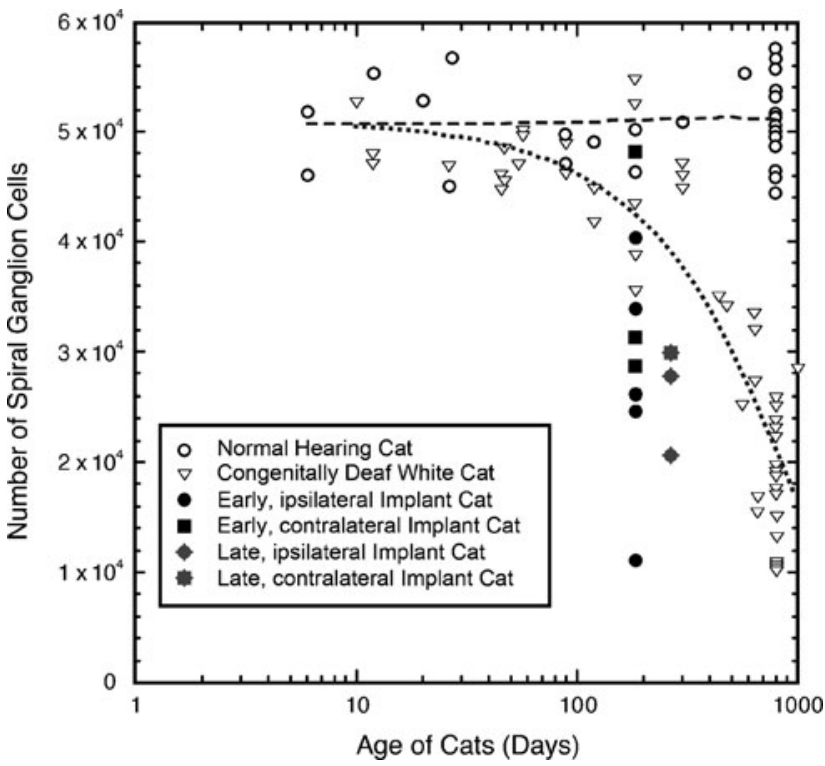

FIG. 9. Plot of spiral ganglion cell counts from normal-hearing (open circles) and congenitally deaf white (open triangles) cats with respect to age, along with polynomial curve fits for normal (dash line) and deaf (dotted line) cats. Ganglion cell counts were combined with values provided in the published record (Howe 1934; Gacek and Rasmussen 1961; Mair 1973). Note that for the first 2 months of life, hearing and congenitally deaf cats have very similar values for ganglion cell numbers. Starting between the third and fourth month, there is a relatively steady loss of ganglion cells until at 3 years of age, ganglion cell counts average just under half to original complement. Cats with cochlear implants exhibit fewer ganglion cells compared to those with no implant (filled symbols), suggesting that some aspect of cochlear implantation is injurious to ganglion cells. Adults whose ages were not given in the published articles were arbitrarily assigned the age of 800 days.

there was a slight but non-significant increase in cell size in the base of the cochlea in closest proximity to the electrodes (Fig. 11A). However, the average cell areas of both congenitally deaf and implanted cats were statistically smaller than those of normal-hearing cats $(p<0.05$, Tukey-Kramer HSD). There was no statistically significant effect of electric stimulation via the cochlear implant on ganglion cell size when comparing the ipsilateral and contralateral side (Fig. 11B, $p=0.46$, Tukey-Kramer HSD). In an implanted but unstimulated congenitally deaf control animal, there was both a reduction in spiral ganglion cell number (Fig. 8) and somatic size (Fig. 11B) as a result of implantation alone (Figs. 12 and 13).

\section{DISCUSSION}

This report presents observations on the effects of cochlear implantation on the histopathology of the inner ear in congenitally deaf cats in comparison to both normal-hearing and congenitally deaf cats without cochlear implantation. In other studies based on this same group of cats, we showed that electrical

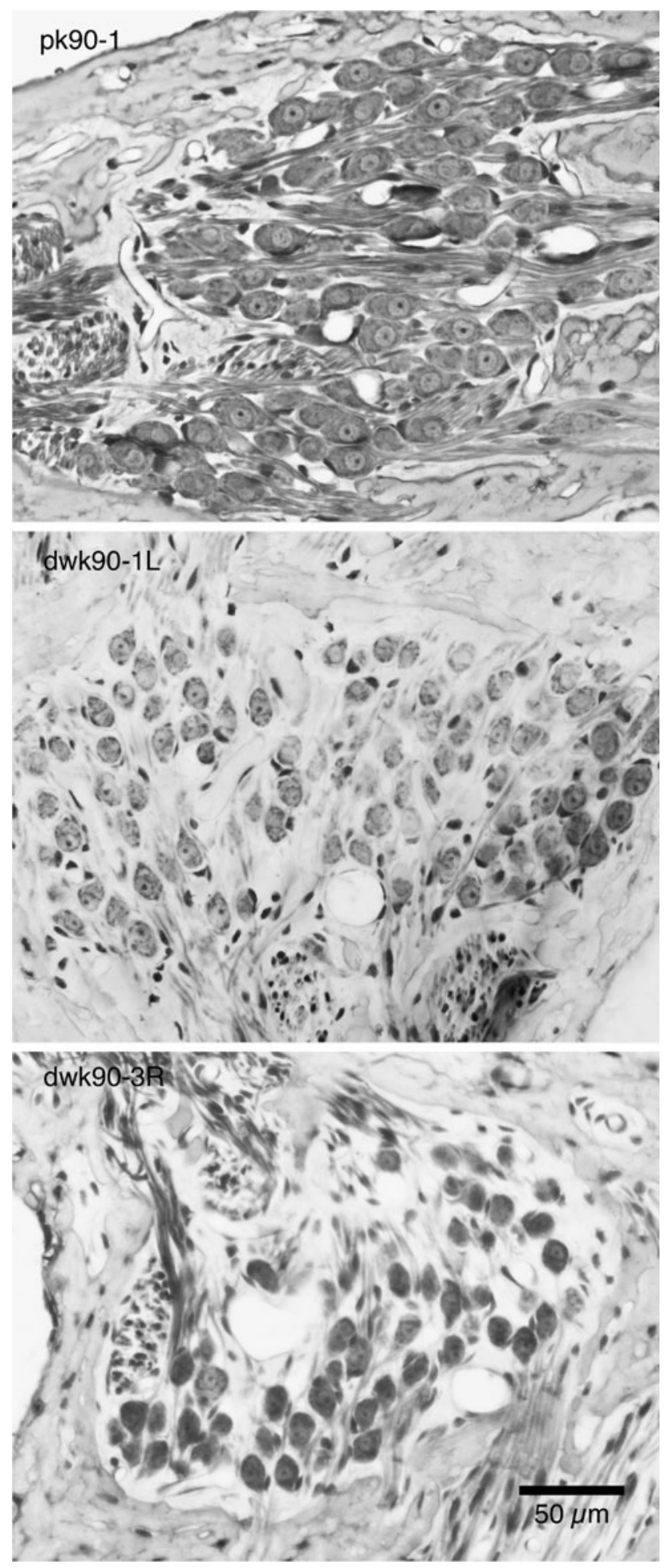

FIG. 10. Photomicrographs of the spiral ganglia of 90-day-old cats with normal hearing (pk90-1) and congenital deafness (dwk90-1L and dwk-90-3R). The normal-hearing cat has its full complement of primary neurons indicated by the normal neuron density and lack of "empty" space. In contrast, the ganglia of the congenitally deaf cats show a reduction in somatic size and lower neuron density due to an increase in "empty" space. Quantitatively, this change reflects a $13.7 \%$ loss in cell number. 

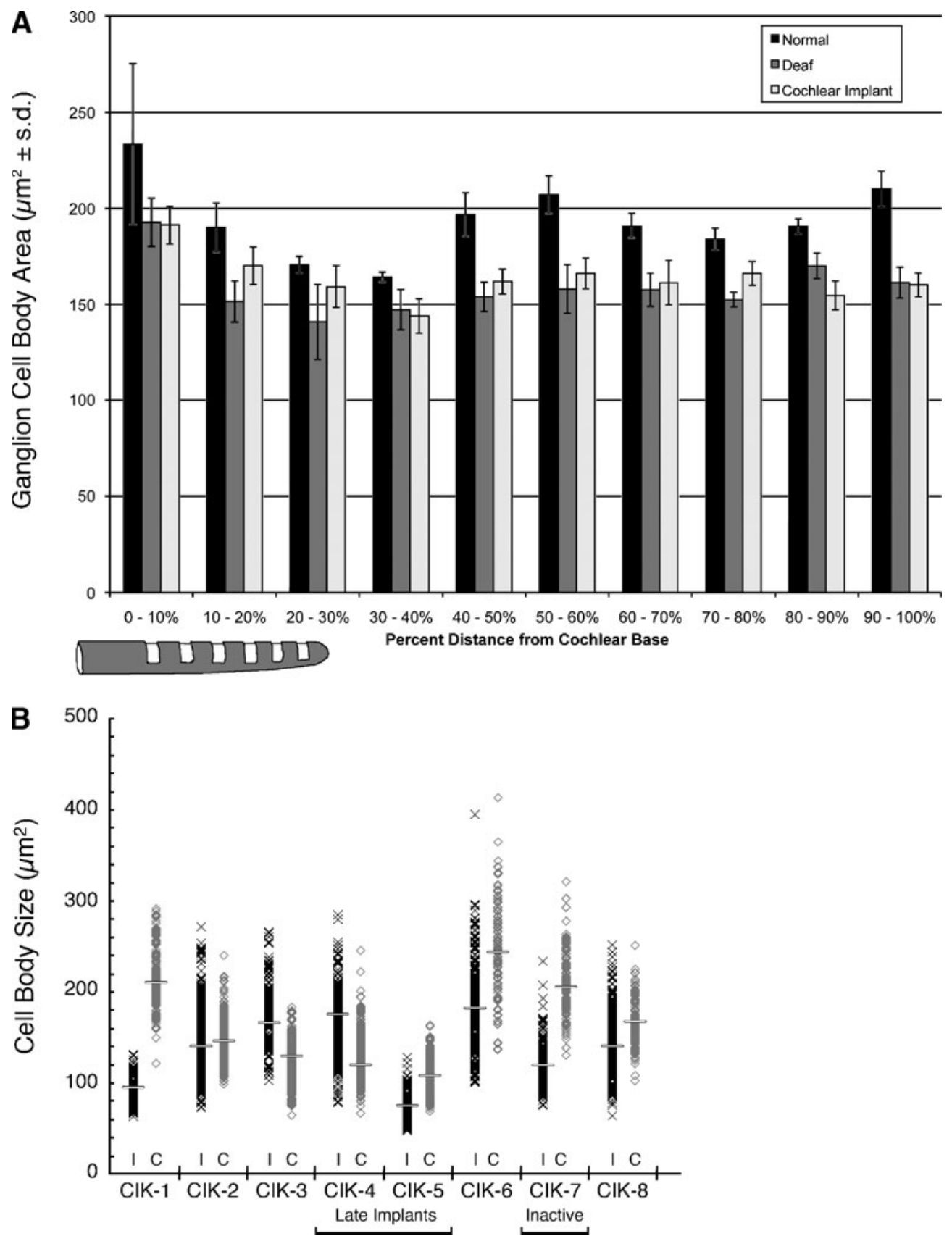

FIG. 11. Analysis of ganglion cell size. A Bar graph illustrating the relationship of ganglion cell body size (mean \pm SEM) with respect cochlear place for normal hearing (black bars), congenitally deaf (gray bars), and congenitally deaf cats with cochlear implant (light bars). The location of the cochlear implant electrode in the cochlea of implanted cats is also shown. There is no statistically significant

effect on cell size by electrical stimulation when comparing data from the left-sided ganglia of implanted and unimplanted congenitally deaf cats. B Scatter plot of all spiral ganglion cell body measurements for ipsilateral and contralateral sides. This within-cat comparison for all implanted cats shows no systematic effect of direct electrical stimulation on ganglion cells.

stimulation via the cochlear implant restored auditory nerve synapses (Ryugo et al. 2005; O'Neil et al. 2010). In these reports, various morphometric calculations were used to determine that electrical stimulation via cochlear implantation does not result in increased spiral ganglion cell density or soma size. These results are similar to previous observations where it was noted that chronic electrical stimulation did not result in more

robust ganglion cell somata or prevent reductions in spiral ganglion cell density for severely deaf subjects (e.g., Coco et al. 2007). Such results are contrary to reports that electrical stimulation promotes both the density and size of spiral ganglion cells (Leake et al. 1999). However, it should be emphasized that the circumstances and variables involved in these other studies differed from those in the present report. 


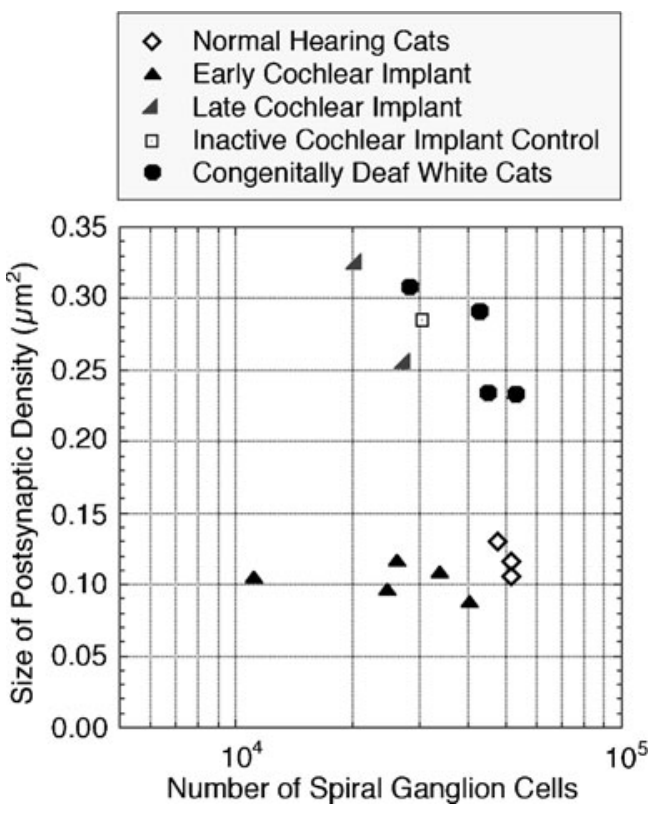

FIG. 12. Plot of the size of postsynaptic densities in ipsilateral auditory nerve endings in the anteroventral cochlear nucleus in response to electrical stimulation via cochlear implantation $\left(\mathrm{O}^{\prime} \mathrm{Neil}\right.$ et al. 2010) with respect to ganglion cell number. These data illustrate that restoration of the size of auditory nerve synapses is attributable to electrical stimulation rather than ganglion cell survival.

The animals in this study inherited their deafness. They were born from families with long histories of congenital deafness (Ryugo et al. 1997, 1998, 2003, 2005), resulting in a form of hearing loss that occurred naturally within the first week of postnatal life (Scheibe 1892; Elverland and Mair 1980). Loss of the sensory apparatus is also apparent during this period and is unambiguously associated with deafness (Mair 1973; Ryugo et al. 2005). Importantly, hearing thresholds do not change with age in white cats (Ryugo et al. 2003); when followed over time, hearing cats retained their hearing, hearing-impaired cats remained hearingimpaired, and deaf cats stayed deaf. The concurrence of early-onset hearing loss with inner ear malformation is strong evidence that these cats never hear (Mair 1973).

The morphological phenotype reported for the hereditarily deaf white cat has been well documented as spontaneously occurring with a wide variability of the expression of the deafness (Bosher and Hallpike 1965; Bergsma and Brown 1971; Mair 1973; Ryugo et al. 1998). The deafness can be bilateral and complete, unilateral, or absent. Moreover, the degree of deafness can range from absolute to mild for the above cases. In short, the kinds of variability observed in these cats resemble the variations in severity observed in humans. As a result, the congenitally deaf white cat presents an opportune model for studying human deafness.
The other model for human congenital deafness uses daily administration of ototoxic drugs to produce deafness in normal kittens that can require as many as 20 such treatments (Leake et al. 1991, 1999; Fallon et al. 2008). This method of chemical deafening by eliminating hair cell receptors, while ultimately effective in abolishing auditory responses, does not eliminate the possibility that the kittens experience some hearing before they are completely deafened, thereby introducing potential complications for the study of congenital deafness. Ototoxic drugs appear to have a direct effect on ganglion cells, causing cell death at a significantly faster rate than observed with other forms of deafness (Mair 1973; Webster and Webster 1981; Keithley and Feldman 1983; Leake et al. 2008). In addition, ototoxic drug administration raises the possibility of indirect injurious effects on cochlear cells as a consequence of damage to supporting cells. In contrast to the rapid disappearance of myelinated peripheral processes in the osseous spiral lamina of ototoxically deafened cats (Terayama et al. 1977; Shepherd and Hardie 2001), myelinated fibers in the osseous spiral lamina of hereditary deafened white cats can survive for years (Heid et al. 1998), a circumstance that could enhance the effects of electrical stimulation via a cochlear implant.

The potential influence of direct drug effects on ganglion cell survival is thus difficult to separate from other variables such as duration of deafness, age at onset of deafness, and stimulation parameters.

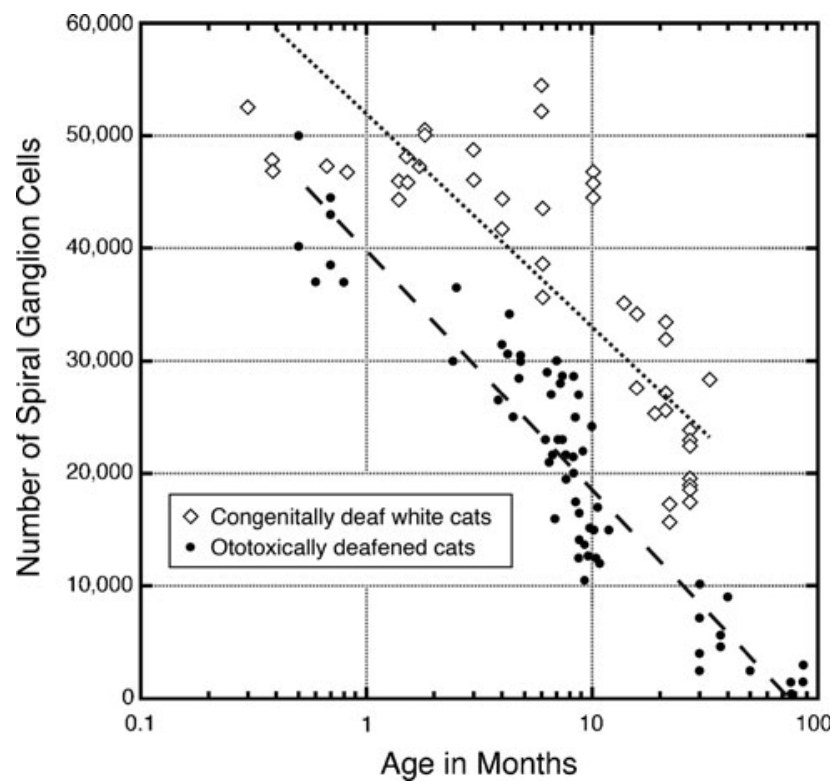

FIG. 13. Plot of ganglion cell number with respect to age (duration of deafness) comparing hereditary deafness (open diamonds) to ototoxic deafness (closed circles). Logarithmic curve fits show more rapid ganglion cell loss for ototoxically deaf cats (dashed line) compared to that of hereditary deaf cats (dotted line). These data support the notion that the two forms of deafness are not equivalent (Mair 1973; Leake and Rebscher 2004). 
Regardless of the possible generalized effects of drugs on spiral ganglion neurons, electrical stimulation of ototoxically deafened cats partially restored auditory nerve synapses. The partial restoration consisted of returning the size and shape of postsynaptic densities to that of normal-hearing cats, but not synaptic vesicle density (Ryugo et al. 2010). It is in this context that the current study addressed the effects, if any, of cochlear implantation on ganglion cells in congenitally deaf cats.

Although the inner ears of congenitally deaf cats appear normal at birth, by the beginning of the second week, the pathologic collapse of Reissner's membrane onto the organ of Corti is evident. By 3 weeks of age, the cochlear duct is obliterated from base to apex, and there is a corresponding loss of the organ of Corti (Mair 1973; Baker et al. 2010). The stria vascularis is also obviously atrophic along the cochlear length. In contrast to findings in ototoxically deafened animals, we observed the persistence (albeit at a reduced level) of myelinated fibers in the osseous spiral lamina of congenitally deaf animals, and ganglion cell survival, while variable, was nonetheless evident. It should be emphasized that the animals we studied here never developed any measurable natural hearing at any point in their lives. At 3 months of age, they were unilaterally implanted with a cochlear implant designed specifically for use in cats. The cats received $7 \mathrm{~h}$ of stimulation per day, 5 days a week, for just over 2 months. As previously mentioned, each cat learned to approach its food bowl when presented with a specific acoustic stimulus (a bugle call). Because of consistent and unambiguous behavioral responses, it was clear that these implanted cats cognitively processed environmental sound stimuli.

A third model of experimentally induced deafness that has been occasionally used employs traumatizing exposure to high-level noise, which produces rapid onset of hair cell damage and hearing loss (Miller et al. 1963; Liberman and Kiang 1978; Puel et al. 1998). Brief exposures that result in the recovery of hair cell function have been shown to have complex effects (Kujawa and Liberman 2009). Hair cell recovery, as documented by microscopic criteria, is associated with a return of ABR thresholds to normal (Liberman and Mulroy 1982). It should be emphasized, however, that "recovery" of thresholds might not reflect adequate criteria for assessing recovery of function. At a subcellular level, there is also a rapid postexposure loss of presynaptic ribbons, one of the key components to the afferent synapse (Kujawa and Liberman 2009). Surprisingly, even with intact hair cells, there was a slow but significant degeneration with diffuse loss of spiral ganglion cells. Perhaps more alarming is that the usual electrophysiological and behavioral methods for detecting acoustic thresholds are insensitive to diffuse neuronal loss (Schuknecht and Woellner 1953; Kujawa and Liberman 2009; El-Badry and McFadden 2007). The observation in human temporal bones that ganglion cell loss can occur without obvious damage to hair cells (Teufert et al. 2006; Linthicum and Fayad 2009) raises further questions related to ganglion cell survival following inner ear trauma.

It is axiomatic that benefits derived from cochlear implantation are mediated by the health of spiral ganglion cells. Open-set speech recognition is a key indicator of clinical success for humans who have received cochlear implants. Variables that influence implant outcomes include duration of deafness, cause of deafness, and ganglion cell survival (Otte et al. 1978; Nadol et al. 1989; Moore et al. 1997; Linthicum and Fayad 2009). Other possible peripheral variables that are more difficult to assess are degree of auditory nerve fiber myelination, peripheral process survival, proximity of electrodes to primary neurons, amount of scar tissue resulting from surgical trauma and implantation, and blood supply to primary neurons. Ganglion cell status is obviously important since cochlear implants could not function without the presence of some surviving cells. The issue of how many neurons are required and to what extent benefit is positively correlated to this number remains an open question. There could be a minimum number of ganglion cells that sets a threshold for benefit achieved. These data point to the significance of the brain in processing auditory nerve signals. We found that synaptic rescue in auditory nerve endings of congenitally deaf cats (O'Neil et al. 2010) did not appear related to the number of surviving spiral ganglion cells as long as some were present (Fig. 8). The myelination of surviving fibers in the osseous spiral lamina, the extent of scar formation around the cochlear implant electrodes, and proximity to the stimulating electrodes were also not significant variables for this effect.

The observation that spiral ganglion cell survival is not strongly correlated to auditory performance or clinical outcomes following cochlear implantation is somewhat enigmatic. There are inconsistent relationships between electrical stimulation and the "health" of primary neurons, and it remains to be determined if surgical trauma of cochlear implantation or electrical stimulation itself counteract the positive effects of spike activity in the auditory nerve. What maybe more pertinent is the "status" of the central auditory system. It is common knowledge, for example, that some people have perfect pitch, some are tone deaf, others have a facility for language, and still others are mathematical. In this context, one's potential to use a cochlear implant might not be uniform even when many features of the deafness are the same. Normalhearing humans have approximately 30,000 myelinated 
auditory nerve fibers innervating 3,000 inner hair cells (Rasmussen 1940; Bredberg 1968). This "input system" is severely reduced by cochlear implants that provide a maximum of 24 channels (electrodes). In spite of the limitations of cochlear implants in spectral resolution (Limb 2006), some implant users achieve high performance scores on speech comprehension, whereas others do not (Waltzman 2006; Giraud and Lee 2007). The variability in user performance and benefits gained by cochlear implant users implies that a key consideration is the brain and its organization.

In conclusion, auditory nerve activity caused by electrical stimulation did not trigger trophic effects that enhanced spiral ganglion cell survival or somatic growth, at least for the time periods used in this study. Although the total hours of electrical stimulation did not influence ganglion cell morphology or survival in this study, it might be that longer periods of stimulation could result in a different outcome. Regardless, cochlear-implanted cats displayed conspicuous spiral ganglion cell loss within the $30-70 \%$ interval of the cochleae, consistent with previous findings of spiral ganglion cell survival with deafness (Elverland and Mair 1980). Despite the spiral ganglion cell loss we observed, implanted animals were clearly able to perceive environmentally relevant sounds and distinguish them from other sounds. The available data also imply that naturally occurring deafness, such as in the congenitally deaf white cat, represents a model for deafness with certain advantages in terms of data interpretation compared to those models produced by ototoxicity or acoustic trauma.

\section{ACKNOWLEDGMENTS}

The authors gratefully acknowledge the contributions of Erika Kretzmer, Karen Montey, Tan Pongstaphone, and San Yu. This work was supported by NIH grants DC000232 and DC005211, the Emma Liepmann Endowment Fund, and a grant from the Advanced Bionics Corporation. Dr. Limb is a consultant for Advanced Bionics Corporation and receives support for unrelated work.

\section{REFERENCES}

Anniko M (1985) Principles in cochlear toxicity. Arch Toxicol Suppl 8:221-239

Araki S, Kawano A, Seldon HL, Shepherd RK, Funasaka S, Clark GM (1998) Effects of chronic electrical stimulation on spiral ganglion neuron survival and size in deafened kittens. Laryngoscope 108:687-695

Araki S, Kawano A, Seldon HL, Shepherd RK, Funasaka S, Clark GM (2000) Effects of intracochlear factors on spiral ganglion cells and auditory brain stem response after long-term electrical stimulation in deafened kittens. Otolaryngol Head Neck Surg 122:425-433

Baker CA, Montey KL, Pongstaporn T, Ryugo DK (2010) Postnatal development of end bulbs of Held in the congenitally deaf cat. Front Neuroanat 4(19):1-14

Bergsma D, Brown K (1971) White fur, blue eyes, and deafness in the domestic cat. J Hered 62:171-185

Bosher SK, Hallpike CS (1965) Observations on the histological features, development, and pathogenesis of the inner ear degeneration of the deaf white cat. Proc R Soc Lond B Biol Sci 162:147-170

Bredberg G (1968) Cellular pattern and nerve supply of the human organ of Corti. Acta Otolaryngol Suppl 236:1-135

Coco A, Epp SB, Fallon JB, Xu J, Millard RE, Shepherd RK (2007) Does cochlear implantation and electrical stimulation affect residual hair cells and spiral ganglion neurons? Hear Res 225:60-70

EL-BAdRY MM, McFadden SL (2007) Electrophysiological correlates of progressive sensorineural pathology in carboplatin-treated chinchillas. Brain Res 1134:122-130

ElverLand HH, Mair IW (1980) Hereditary deafness in the cat. An electron microscopic study of the spiral ganglion. Acta Otolaryngol 90:360-369

Fallon JB, Irvine DR, Shepherd RK (2008) Cochlear implants and brain plasticity. Hear Res 238:110-117

FAYAD JN, Linthicum FH JR (2006) Multichannel cochlear implants: relation of histopathology to performance. Laryngoscope 116:1310-1320

Gacek RR, Rasmussen GL (1961) Fiber analysis of the statoacoustic nerve of guinea pig, cat and monkey. Anat Rec 139:455-463

Giraud AL, Lee HJ (2007) Predicting cochlear implant outcome from brain organisation in the deaf. Restor Neurol Neurosci 25:381-390

Guillery RW (2002) On counting and counting errors. J Comp Neurol 447:1-7

HARDIE NA, SHEPHERD RK (1999) Sensorineural hearing loss during development: morphological and physiological response of the cochlea and auditory brainstem. Hear Res 128:147-165

Hartshorn DO, Miller JM, Altschuler RA (1991) Protective effect of electrical stimulation in the deafened guinea pig cochlea. Otolaryngol Head Neck Surg 104:311-319

Hawkins JE JR (1973) Comparative otopathology: aging, noise, and ototoxic drugs. Adv Otorhinolaryngol 20:125-141

Heid S, Hartmann R, Kuinke R (1998) A model for prelingual deafness, the congenitally deaf white cat-population statistics and degenerative changes. Hear Res 115(1-2):101-112

Howe HA (1934) The reaction of the cochlear nerve to destruction of its end organs: a study on deaf albino cats. J Comp Neurol 62:73-79

Keithley EM, Feldman ML (1983) The spiral ganglion and hair cells of Bronx waltzer mice. Hear Res 12:381-391

Keithley EM, Schreiber RC (1987) Frequency map of the spiral ganglion in the cat. J Acoust Soc Am 81:1036-1042

Khan AM, Whiten DM, Nadol JB JR, Eddington DK (2005a) Histopathology of human cochlear implants: correlation of psychophysical and anatomical measures. Hear Res 205:8393

Khan AM, Handzel O, Burgess BJ, Daimian D, Eddington DK, Nadol JB JR (2005b) Is word recognition correlated with the number of surviving spiral ganglion cells and electrode insertion depth in human subjects with cochlear implants? Laryngoscope 115:672-677

Kiang NYS, Rho JM, Northrop CC, Liberman MC, Ryugo DK (1982) Hair-cell innervation by spiral ganglion cells in adult cats. Science 217:175-177

Kretzmer EA, Meltzer Ne, Haenggeli CA, Ryugo DK (2004) An animal model for cochlear implants. Arch Otolaryngol Head Neck Surg 130:499-508 
KujaWa SG, Liberman MC (2009) Adding insult to injury: cochlear nerve degeneration after "temporary" noise-induced hearing loss. J Neurosci 29:14077-14085

Leake PA, Hradek GT (1988) Cochlear pathology of long term neomycin induced deafness in cats. Hear Res 33:11-33

Leake PA, Hradek GT, Rebscher SJ, Snyder RL (1991) Chronic intracochlear electrical stimulation induces selective survival of spiral ganglion neurons in neonatally deafened cats. Hear Res 54:251-271

Leake PA, Hradek GT, Snyder RL (1999) Chronic electrical stimulation by a cochlear implant promotes survival of spiral ganglion neurons after neonatal deafness. J Comp Neurol 412:543-562

LeAKe PA, Rebscher S (2004) Anatomical considerations and longterm effects of electrical stimulation. In: Zeng F-G, Popper AN, Fay RR (eds) Auditory prostheses. Springer handbook of auditory research. Springer, New York, pp 101-148

Leake PA, Stakhovskaya O, Hradek GT, Hetherington AM (2008) Factors influencing neurotrophic effects of electrical stimulation in the deafened developing auditory system. Hear Res 242:86-99

Li L, Parkins CW, Webster DB (1999) Does electrical stimulation of deaf cochleae prevent spiral ganglion degeneration? Hear Res 133:27-39

Liberman MC, Kiang NYS (1978) Acoustic trauma in cats. Acta Otolaryngol (Suppl) 358:1-63

Liberman MC, Mulroy MJ (1982) Acute and chronic effects of acoustic trauma: cochlear pathology and auditory nerve pathophysiology. In: Hamernik RP, Henderson D, Salvi R (eds) New perspectives on noise-induced hearing loss. Raven, New York, pp $105-136$

Limb CJ (2006) Cochlear implant-mediated perception of music. Curr Opin Otolaryngol Head Neck Surg 14:337-340

Linthicum FH JR, FaYAd JN (2009) Spiral ganglion cell loss is unrelated to segmental cochlear sensory system degeneration in humans. Otol Neurotol 30:418-422

Lousteau RJ (1987) Increased spiral ganglion cell survival in electrically stimulated, deafened guinea pig cochleae. Laryngoscope 97:836-842

Lustig LR, Leake PA, SNyder RL, Rebscher SJ (1994) Changes in the cat cochlear nucleus following neonatal deafening and chronic intracochlear electrical stimulation. Hear Res 74:29-37

MaIR IW (1973) Hereditary deafness in the white cat. Acta OtoLaryngol (Suppl) 314:1-48

Miller JD, Watson CS, Covell WP (1963) Deafening effects of noise on the cat. Acta Oto-laryngol (Suppl) 176:1-91

Mitchell A, Miller JM, Finger PA, Heller JW, Raphael Y, Altschuler RA (1997) Effects of chronic high-rate electrical stimulation on the cochlea and eighth nerve in the deafened guinea pig. Hear Res 105:30-43

Moore JK, Niparko JK, Miller Mr, Perazzo LM, Linthicum FH (1997) Effect of adult-onset deafness on the human central auditory system. Ann Otol Rhinol Laryngol 106:385-390

Nadol JB JR, Young YS, GLYNN RJ (1989) Survival of spiral ganglion cells in profound sensorineural hearing loss: implications for cochlear implantation. Ann Otol Rhinol Laryngol 98:411-416

Nadol JB Jr, Shiao JY, Burgess BJ, Ketten DR, Eddington DK, Gantz BJ, Kos I, Montandon P, Coker NJ, Roland JT Jr, Shallop JK (2001) Histopathology of cochlear implants in humans. Ann Otol Rhinol Laryngol 110:883-891

O’Neil JN, Limb CJ, Baker CA, Ryugo DK (2010) Bilateral effects of unilateral cochlear implantation in congenitally deaf cats. J Comp Neurol 518:2382-2404
Otte J, Schunknecht HF, KerR AG (1978) Ganglion cell populations in normal and pathological human cochleae. Implications for cochlear implantation. Laryngoscope 88:1231-1246

Puel JL, Ruel J, Gervais d’Aldin C, Pujol R (1998) Excitotoxicity and repair of cochlear synapses after noise-trauma induced hearing loss. NeuroReport 9:2109-2014

Rasmussen GL (1940) Studies of the VIIIth cranial nerve of man. Laryngoscope 50:67-83

Rubel EW, Hyson RL, Durham D (1990) Afferent regulation of neurons in the brain stem auditory system. J Neurobiol 21:169-196

Ryugo DK, Pongstaporn T, Hughton DM, Niparko JK (1997) Ultrastructural analysis of primary endings in deaf white cats: morphologic alterations in end bulbs of Held. J Comp Neurol 385:230-244

Ryugo DK, Rosenbaum BT, Kim PJ, Niparko JK, SaAda AA (1998) Single unit recordings in the auditory nerve of congenitally deaf white cats: morphological correlates in the cochlea and cochlear nucleus. J Comp Neurol 397:532-548

Ryugo DK, Cahill HB, Rose LS, Rosenbaum BT, Schroeder ME, Wright AL (2003) Separate forms of pathology in the cochlea of congenitally deaf white cats. Hear Res 181:73-84

Ryugo DK, Kretzmer EA, Niparko JK (2005) Restoration of auditory nerve synapses in cats by cochlear implants. Science 310:1490-1492

Ryugo DK, Baker CA, Montey KL, Chang LY, Coco A, Fallon JB, SHEPHERD RK (2010) Synaptic plasticity after chemical deafening and electrical stimulation of the auditory nerve in cats. J Comp Neurol 518:1046-1063

SCHeIBE A (1892) A case of deaf-mutism, with auditory atrophy and anomalies of development in the membranous labyrinth of both ears. Arch Otol 21:12-22

Schuknecht H (1993) Pathology of the ear. Harvard University Press, Cambridge

Schuknecht HF, Woellner RC (1953) Hearing losses following partial section of the cochlear nerve. Laryngoscope 63:441-465

SHEPHERD RK, MARTIN RL (1995) Onset of ototoxicity in the cat is related to onset of auditory function. Hear Res 92:131-142

Shepherd RK, Matsushima J, Martin RL, Clark GM (1994) Cochlear pathology following chronic electrical stimulation of the auditory nerve: II. Deafened kittens. Hear Res 81:150-166

SHEPHERD RK, HARDIE NA (2001) Deafness-induced changes in the auditory pathway: implications for cochlear implants. Audiol Neurootol 6:305-318

Shepherd RK, Meltzer NE, Fallon JB, Ryugo DK (2006) Consequences of deafness and electrical stimulation on the peripheral and central auditory system. In: Waltzman SB, Roland JT Jr (eds) Cochlear implants. Thieme, New York, pp 25-39

SpoendLin H (1984) Factors inducing retrograde degeneration of the cochlear nerve. Ann Otol Rhinol Laryngol (Suppl) 112:76-82

Terayama Y, Kaneko Y, Kawamoto K, Sakai N (1977) Ultrastructural changes of the nerve elements following disruption of the organ of Corti. I. Nerve elements in the organ of Corti. Acta Otolaryngol 83:291-302

Teufert KB, Linthicum FH Jr, Connell SS (2006) The effect of organ of corti loss on ganglion cell survival in humans. Otol Neurotol 27:1146-1151

WALTZMAN SB (2006) Speech processing in children with cochlear implants. In: Waltzman SB, Roland JT Jr (eds) Cochlear implants. Thieme, New York, pp 146-152

Webster M, Webster DB (1981) Spiral ganglion neuron loss following organ of Corti loss: a quantitative study. Brain Res 212:17-30

WiLson BS, Dorman MF (2008) Cochlear implants: a remarkable past and a brilliant future. Hear Res 242:3-21 